\title{
A NEW SPECIES OF LEPANTHES \\ (ORCHIDACEAE: PLEUROTHALLIDINAE) FROM COLOMBIA WITH A LARGE AND PROTRUDING COLUMN
}

\author{
Juan Sebastián Moreno ${ }^{1,6}$, Sebastián Vieira-Uribe ${ }^{2,3}$ \& Adam P. Karremans ${ }^{4,5}$ \\ ${ }^{1}$ Fundación Ecotonos, Cali, Colombia \\ ${ }^{2}$ Sociedad Colombiana de Orquideología, Medellín, Colombia \\ ${ }^{3}$ Grupo de investigación en biodiversidad tropical - GIBIOT, Jardín Botánico de Medellín, Colombia \\ ${ }^{4}$ Lankester Botanical Garden, University of Costa Rica, P.O. Box 302-7050 Cartago, Costa Rica. \\ ${ }^{5}$ Naturalis Biodiversity Center, Leiden, The Netherlands \\ ${ }^{6}$ Author for correspondence: semoreno113@gmail.com
}

\begin{abstract}
A new species of Lepanthes from the Western Cordillera of the Colombian Andes, characterized by similar triangular sepals with a large and protruding column, is described and illustrated. The new species is similar to Lepanthes pelorostele from Ecuador, but can be distinguished from the latter by having orange and ciliate sepals and larger petals and lip.
\end{abstract}

Resumen. Se describe e ilustra una nueva especie de Lepanthes de la Cordillera Occidental de los Andes colombianos caracterizada por tener sépalos triangulares similares y una columna sobresaliente. Esta nueva especie es similar a Lepanthes pelorostele, de Ecuador, pero se puede distinguir de esta última por tener sépalos ciliados, anaranjados y pétalos y labelo más grandes.

KEY WORDS: Colombia, endemism, taxonomy, trilobed petals, Western Cordillera

Introduction. With 1120 accepted species, Lepanthes Sw. is currently one of the two most species rich genera in the Pleurothallidinae together with Stelis Sw. (Karremans 2016), and one of the richest of the Orchidaceae overall (Pupulin \& Bogarín 2012). Lepanthes occupies the second place in the species list of Colombia after Epidendrum L. with more than 300 species described (Luer \& Thoerle 2012, Bernal et al. 2015) where it reaches their greatest diversity in the Andean region (Luer \& Thoerle 2012). Despite their wide distribution in the country, species in the genus are characterized by its high degree of endemism (Luer \& Thoerle 2012) and specific preferences of habitat (Luer 1996, Crain 2012, Tremblay et al. 1998, Pupulin \& Bogarín 2012), making Lepanthes a highly susceptible group to plant cover loss, stochastic disturbances and anthropic vegetation extraction (Crain \& Tremblay 2014).

Lepanthes species can generally be recognized by the lepanthiform sheaths that are frequently ciliated, pubescent, with a slight to wide apical dilatation, petals that are usually transversely bilobed to trilobed, with a compound lip composed of two thickened blades usually covering the column with a minute basal appendix, which plays an important role in the pseudocopulatory pollination syndrome (Blanco \& Barboza 2005). There are many variations to these features, and several species' groups with particular morphological similarities can be found within the genus (Pupulin \& Bogarín 2010; 2014a; 2014b; Bogarín et al. 2012). Here we present a new species so far known only from the mountains of San José del Salado in Valle del Cauca, Colombia, that might belong to a group of species from southern Central and northern South America characterized mainly by exhibiting similar, triangular sepals with a long, conspicuous and protruding column.

\section{TAXONOMIC TREATMENT}

Lepanthes vargasii J.S.Moreno, S.Vieira-Uribe \& Karremans, sp. nov. (Fig. 1, 2).

TYPE: Colombia. Valle del Cauca: Municipio de Dagua, Corregimiento de San José del Salado, $1860 \mathrm{~m}$. 


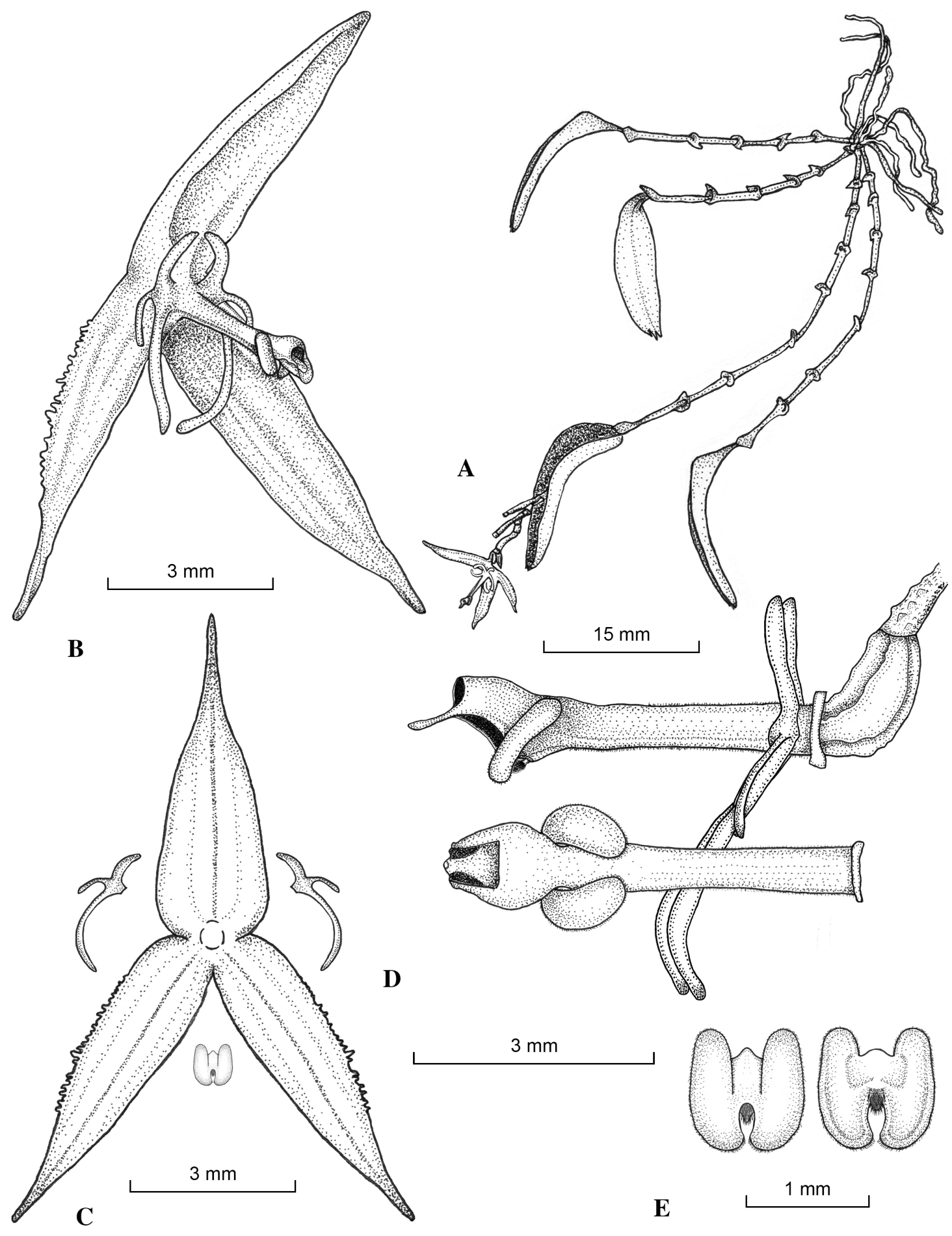

Figure 1. Illustration of Lepanthes vargasii J.S.Moreno, S.Vieira-Uribe \& Karremans. A. Habit. B. Flower. C. Dissected perianth. D. Column, lateral and dorsal view (pollinia and anther cap absent). E. Lip, dorsal and ventral views. Drawn by J.S. Moreno based on J.S Moreno \& A.L. Erazo 342 (CAUP). 

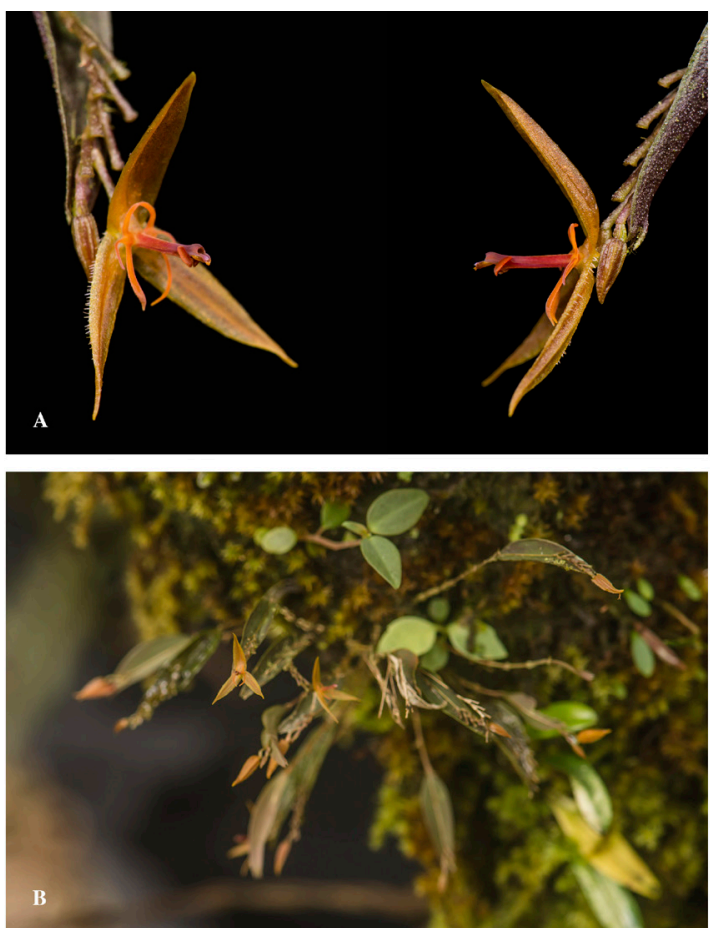

FIGURE 2. Photographs of Lepanthes vargasii. A. Flower. B.

Habit and plant, in-situ. Photographs by J.S. Moreno of the plant that served as type.

Jul. 12 2016. J.S Moreno \& A.L. Erazo 342 (holotype, CAUP!).

Diagnosis: Similar to Lepanthes pelorostele Luer \& Hirtz but distinguished by the orange, ciliate sepals on the exterior margins of the lateral sepals (vs. white and glabrous), the larger petals (the longest (lower) lobe $2 \mathrm{~mm}$, vs. $0.5 \mathrm{~mm}$ long) and the larger lip (1.0 vs. 0.3 $\mathrm{mm}$ long), that is placed at the column apex (vs. placed basally).

Plant epiphytic, small, caespitose, suberect to $4.5-5.0 \mathrm{~cm}$ tall. Roots slender, flexuous, filiform, to 0.2 $\mathrm{mm}$ in diameter. Ramicauls slender $2.3-3.3 \mathrm{~cm}$ long, enclosed by $5-11$ lepanthiform sheaths, to $3-7.5 \mathrm{~mm}$ long, microscopically ciliate along the margins, with a dilated ostia, subacuminate. Leaves green suffused on the abaxial surface with purple, subcoriaceous, the abaxial surface verrucose, conduplicate, narrowly ovateelliptic, $1.6-1.8 \times 0.4 \mathrm{~cm}$, the base cuneate contracted into a petiole ca. $1 \mathrm{~mm}$ long, apex tridentate with the tip of the central vein protruding abaxially within the sinus. Inflorescence racemose, congested, distichous, successively flowered, born at the base of the leaf, to $2.2 \mathrm{~cm}$ long; peduncle filiform, terete, to $1.3 \mathrm{~cm}$ long, from the apex of the ramicaul at the base of the leaf; rachis flexuous, to $9 \mathrm{~mm}$ long; floral bract $0.7-1.0 \mathrm{~mm}$ long, ovate, muricate; pedicel terete, verrucose, 1.5$2.0 \mathrm{~mm}$ long. Ovary subclavate, shallowly winged, $1.0-1.3 \mathrm{~mm}$ long. Flowers resupinate, sepals and petals yellow-orange and orange striped along the veins, lip reddish-orange, column red-purple. Sepals similar, 3-veined, shortly connate at the base; dorsal sepal 6 $\times 3 \mathrm{~mm}$, triangular-lanceolate, slightly concave, acute, glabrous; lateral sepals $6 \times 2 \mathrm{~mm}$, narrowly triangularlanceolate, acute, glabrous, ciliate along the exterior margins, translucent. Petals trilobed, lobes filiform, minutely pubescent, spreading $1 \times 3 \mathrm{~mm}$, lower lobe 2 $\mathrm{mm}$ long, mid-lobe and upper lobe $0.8-1.0 \mathrm{~mm}$ long, mid-lobe thinner. Lip connate to the column up to near the apex, blades oblong, the ends rounded, minutely pubescent, long pubescent in the surface of the apex, $0.8-1.0 \mathrm{~mm}$ long, apically loose and embracing the column, connectives broadly cuneate, appendix triangular, falcate, pubescent, reaching the blades. Column $3 \mathrm{~mm}$ long, slender, minutely pubescent, terete, clinandrium dorsal; rostellum and stigma apical. Anther cap not seen. Pollinia not seen.

Eponymy: The name honors Colombian conservationist and botanist William G. Vargas, whose passion and dedication for plants inspired the first author to be immersed in the world of botany and taxonomy.

Distribution AND ECOLOGY: Lepanthes vargasii is found in the Western Cordillera of the Andes in the department of Valle del Cauca, at about 1800-1900 m of elevation (Fig. 3). It has been found growing as an epiphyte next to L. felis Luer \& R. Escobar and L. venusta Luer \& R. Escobar on a Tibouchina lepidota (Bonpl.) Baill. (Melastomataceae) wood fence at $50 \mathrm{~cm}$ from the ground along the edge of a pasture in close proximity to a very well preserved forest.

Lepanthes vargasii (Fig. 2, 5K) with its narrowly triangular-lanceolate sepals, trilobed petals, and lip connate close to the apex of a terete, protruding column to close to the apex (Fig. 5F) shares similar traits with a handful of species from southern Central and northern South America. It resembles the Ecuadorian species, Lepanthes equus-frisiae Pupulin \& H. Medina (Pupulin et al. 2011) (Fig. 4A, 5A), Lepanthes pelorostele 


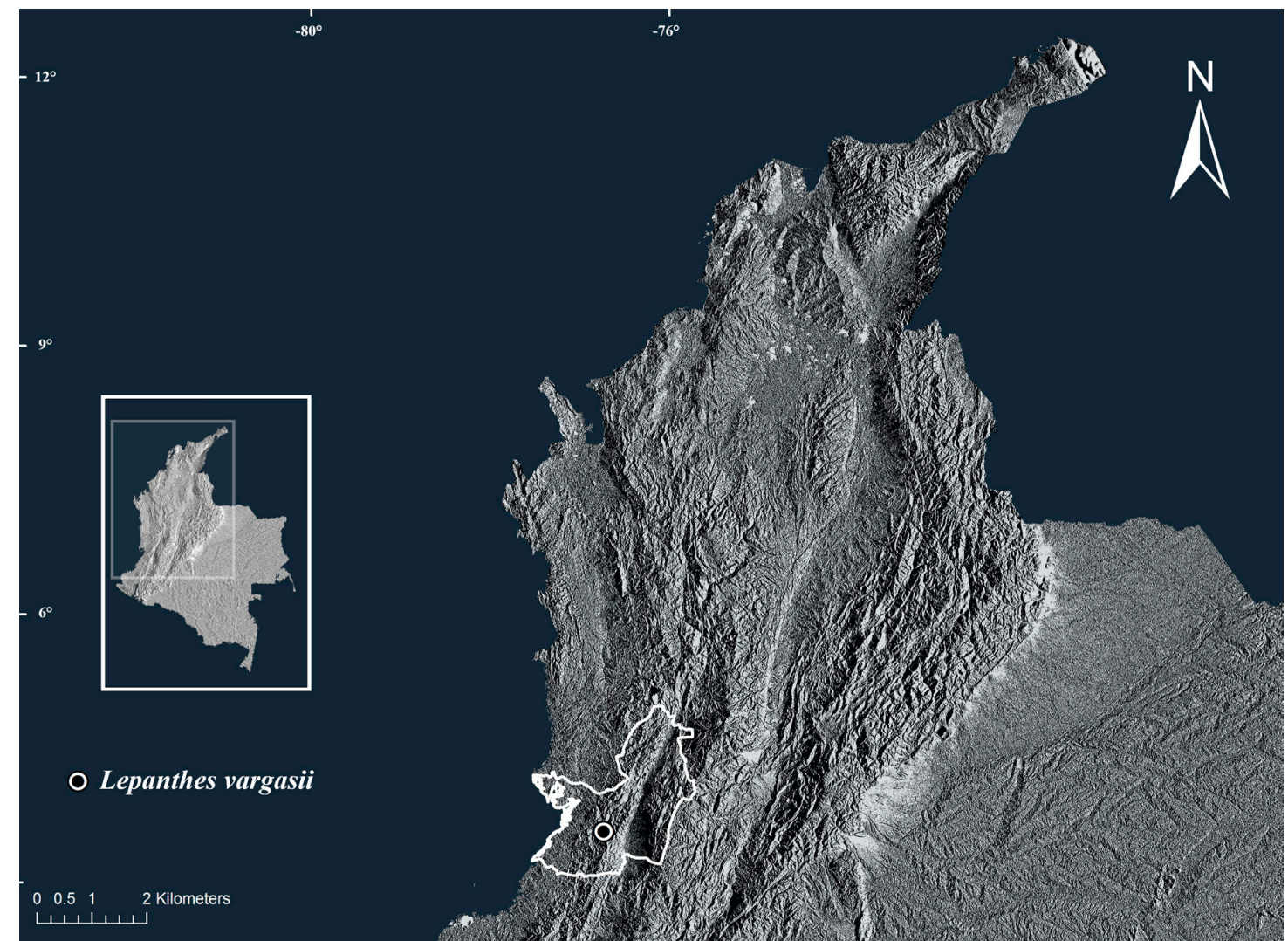

Figure 3. Distribution map of Lepanthes vargasii, located in San José del Salado, Valle del Cauca, Colombia.

Luer \& Hirtz (Fig. 5F), Lepanthes scrotifera Luer \& Hirtz (Fig. 4H, 5I) and Lepanthes rigidigitata Luer \& Hirtz (Fig. 5H). The most similar species is probably Lepanthes pelorostele, a species known only from Pichincha, Ecuador, and characterized by its glabrous, white sepals, 2- veined lateral sepals, trilobed petals between $0.1-0.5 \mathrm{~mm}$ long, trilobed lip with lateral blades embracing the undersurface of an elongate, imposing column. The new species can be distinguished from the latter by the reddish-orange, ciliate along the outer margins, 3-veined lateral sepals, the much larger petals and the larger lip placed at the column apex. Lepanthes equus-frisiae has 1-veined lateral sepals (vs. 3-veined lateral sepal), transversely rheniformsuborbicular, rounded concave petals (vs. trilobed petals), and a subspherical broadly obtuse lip (vs. lip with oblong blades and a minute appendix embracing the column); Lepanthes scrotifera is distinguished by its transversely bilobed petals, long pubescent, $0.25 \times 1.5$ $\mathrm{mm}$ (vs. minutely pubescent trilobed petals, $1.0 \times 3.0$ $\mathrm{mm}$ ), pubescent bilobed lip, with a descending ligulate callus (vs. lip with oblong blades with a pubescent appendix). Finally, Lepanthes rigidigitata with a prolific scandent habit (vs. caespitose and epiphyte), lateral sepals 1-veined (vs. 3-veined), petals transversely ovatehastate, broadly obtuse (vs. trilobed, lobes filiform), lip transversely subquadrate with the sides broadly rounded and curved up (vs. lip with blades oblong, the ends rounded, minutely pubescent, long pubescent in the surface of the apex).

Four Colombian species share similar traits with the new species, Lepanthes eros Luer \& R. Escobar, (Fig. 4B, 5B) Lepanthes isosceles Luer \& R. Escobar (Fig. 4C, 5C), Lepanthes micellilabia Luer \& R. Escobar (Fig. 4D, 5D) and Lepanthes niphas Luer \& R. Escobar (Fig. 4E, 5E) (Luer \& Thoerle 2012). Lepanthes eros, a very small species from the Western and Central Cordillera has 1-veined sepals, $1.75 \times 0.8-1 \mathrm{~mm}$ (vs. 3-veined sepals, $6 \times 2-3 \mathrm{~mm}$ ), petals transversely elliptical (vs. trilobed petals), lip with the blades ovate, embracing the column below the middle with a minute, pubescent lobule appendix at the apex of the sinus (vs. 

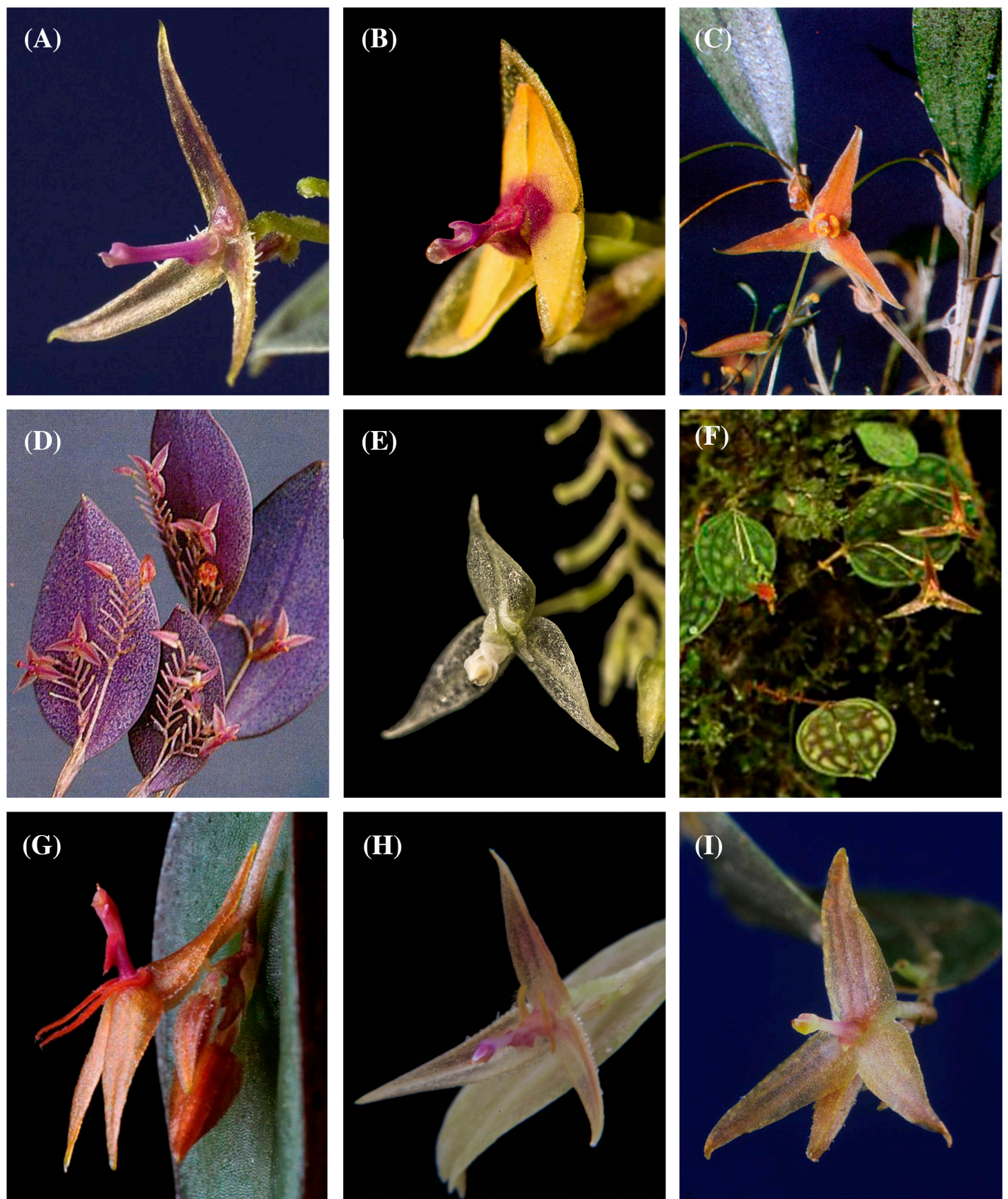

Figure 4. Comparisson of the most similar species to Lepanthes vargasii. A. L. equus-frisiae. B. L. eros. C. L. isosceles.

D. L. micellilabia. E. L. niphas. F. L. posthon. G. L. spadariae. H. L. scrotifera. I. L. vestigialis. Photographs by F. Pupulin (A, I), R. Escobar (C, D), Leon Glicenstein (F), Wiel Driessen (G), Jorge de la Cruz (H) and J.S Moreno (B, E).

lip with blades oblong, embracing the column at the apex and a triangular, falcate, pubescent appendix); Lepanthes isosceles the only species recorded from
Sierra Nevada de Santa Marta, it is characterized by its long, loosely raceme inflorescence (vs. racemose, congest), transversely oblongs petals (vs. trilobed), 
(A)

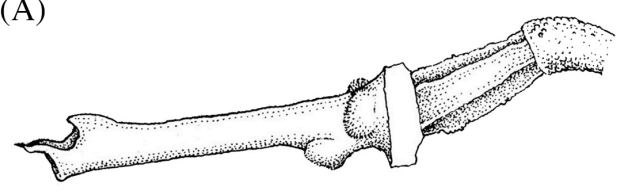

$15 \mathrm{~mm}$

(C)

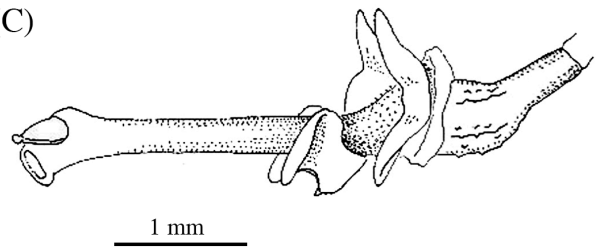

(E)

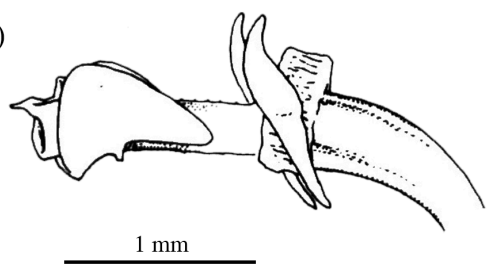

(G)

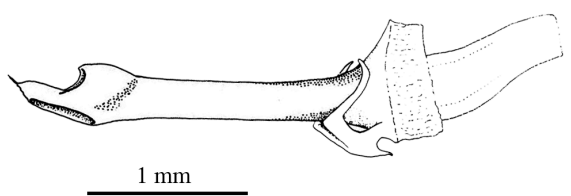

(I)

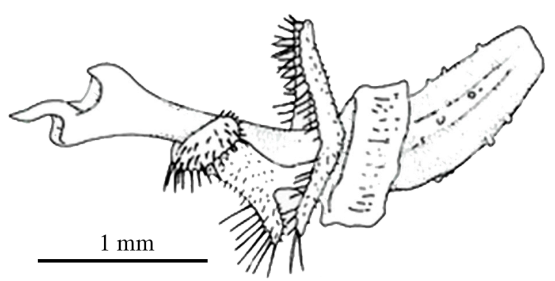

(K)

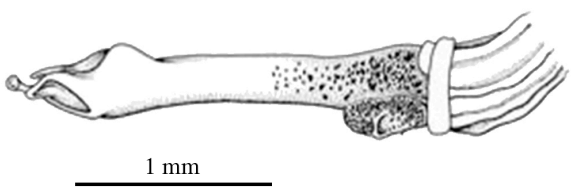

(B)
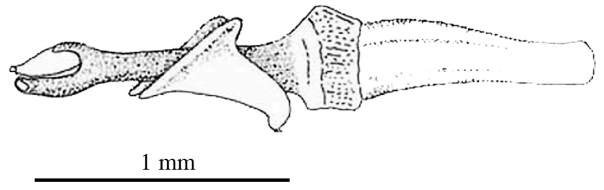

(D)

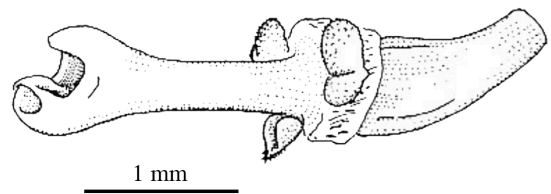

(F)

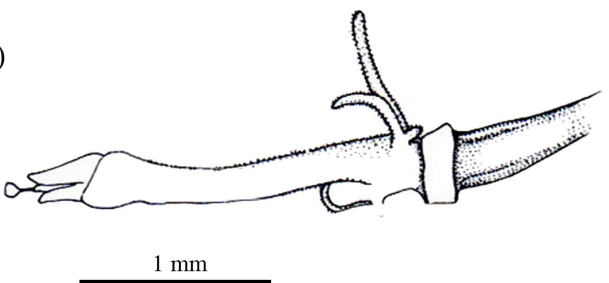

(H)

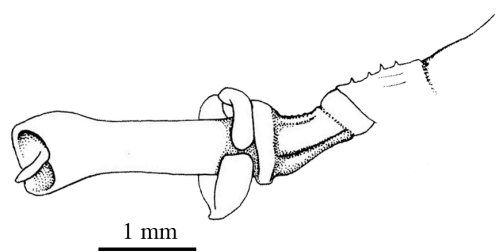

(J)

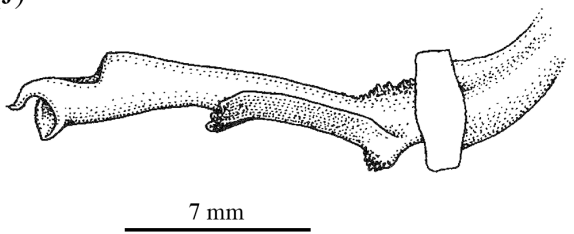

(L)

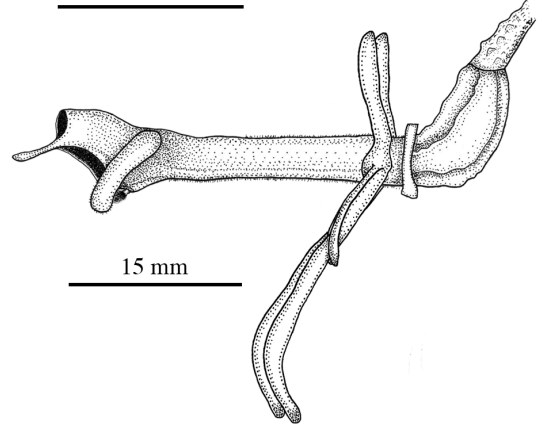

FiguRE 5. Illustrations and comparison of the columns of the most similar species to Lepanthes vargasii. A. L. equus-frisiae.

B. L. eros. C. L. isosceles. D. L. micellilabia. E. L. niphas. F. L. pelorostele. G. L. posthon. H. L. rigidigitata. I. L. scrotifera. J. L. spdariae. K. L. vestigialis. L. L. vargasii. Original drawings by Franco Pupulin (A, J), Diego Bogarín (K), J.S Moreno (L) and Carlyle Luer (B-I) courtesy of the Missouri Botanic Gardens Press and the American Orchid Society. 
oblong-lunate lip, embracing the column above in the base of the column (vs. oblong), minute triangular appendix (vs. pubescent and reaching the blades); Lepanthes micellilabia a species from the department of Antioquia can be distinguish from Lepanthes vargasii by having mainly transversely bilobed petals, $0.25 \times$ 0.5 (vs. trilobed petals, $1.0 \times 3.0 \mathrm{~mm}$ ) and a minute cordate lip at the base of the column, $0.25 \mathrm{~mm}$ long and wide (vs. a lip with oblong blades, $0.8-1.0 \mathrm{~mm}$ long). The last species, Lepanthes niphas with a successively many-flowered raceme up to $15 \mathrm{~mm}$ long (vs. $2.2 \mathrm{~cm}$ long), lateral sepals white, glabrous, 1-veined (vs. yellow orange, ciliate, 3 -veined), petals transversely bilobed (vs. trilobed) and a white lip, bilobed, embracing the column (vs. reddish-orange, with blades oblong, embracing the column at the apex).

From Costa Rica, three species described so far have somewhat similar features, Lepanthes posthon Luer (Luer 1987) (Fig. 4F, 5G), Lepanthes spadariae Pupulin (Pupulin 2001) (Fig. 4G, 5J) and Lepanthes vestigialis Bogarín \& Pupulin (Pupulin et al. 2011) (Fig. 4I, 5K). Lepanthes posthon recognized by its reticulate cordate-ovate leaves (vs. narrowly ovate and conduplicate), petals transversely bilobed bifurcated into a pair of filaments (vs. trilobed), and a bifurcate lip (vs. the blades oblong, embracing the column); Lepanthes spadariae displays petals with long caudate lower lobes and reduced upper lobes (vs. trilobed petals), a protruding column of $1.5 \mathrm{~mm}$ long (vs. column $3.0 \mathrm{~mm}$ long) and a flabellate lip (vs. lip embracing the column near the apex); L. vestigialis has longitudinally similar sepals, $4.0 \times 1.5 \mathrm{~mm}($ vs. $6.0 \times 2.0-3.0 \mathrm{~mm})$ vestigial petals and lip (vs. trilobed petals and oblong minutely pubescent lip with a minute pubescent appendix).

ACKNOWLEDGMENTS. This manuscript was prepared as part of a dedicatory issue commemorating the 95th birthday of Carl Luer, who's extensive work on the Pleurothallidinae is the basis for most current studies in the subtribe, including the present. The first author is especially grateful to José Otocar Reina and his son Juan Fernando Reina for their company and hospitality in the Altos of San José del Salado. We also thank Milton Rincón for his comments on the manuscript. Zuzana Štípková, Juan Ortiz and Alejandro Pinto who organized the fieldtrip to the place where the species was found. Bernardo Ramírez, director and curator of the University of Cauca Herbarium (CAUP), is thanked for his technical guidance in preparing the herbarium material. Franco Pupulin, Diego Bogarín, Hermano Jorge de la Cruz, Wiel Driessen, the Sociedad Colombiana de Orquideología (SCO) and Leon Glicenstein were kind enough to share their photographic material of the species of this group. Two anonymous reviewers improved this manuscript greatly and are thanked. Finally, we would like to say thanks to the Missouri Botanical Gardens Press and the American Orchid Society for letting us use the drawings of the species for comparisons.

\section{LitERATURE CITED}

Bernal, R., Gradstein, S.R. \& Celis, M. (2015). Catálogo de plantas y líquenes de Colombia Instituto de Ciencias Naturales, Universidad Nacional de Colombia, Bogotá. http://catalogoplantasdecolombia.unal.edu.co.

Blanco, M. A. \& G. Barboza. 2005. Pseudocopulatory pollination in Lepanthes (Orchidaceae: Pleurothallidinae) by fungus gnats. Annals of Botany, 95: 763-772. doi: https://doi.org/10.1093/aob/mci090

Bogarín, D. \& D. Jiménez. (2015). Lepanthes Novae Durikaenses. Orchids (Bulletin America of the Orchid Society), 84(7), 430-440.

Crain, B. J. \& Tremblay, R. L. (2014). Do richness and rarity hotspots really matter for orchid conservation in light of anticipated habitat loss?. Diversity and Distribution, 20, 652-662. doi: 10.1111/ddi.12179

Dodson, C.H. \& Luer, C.A. (2011). Orchidaceae, part 7. Lepanthes and affiliates. In: C. Persson \& B. Ståhl (eds), Flora of Ecuador 88. Department of Plant and
Environmental Sciences, University of Gothenburg, Göteborg, Sweden.

Karremans, A.P. (2016). Genera Pleurothallidinarum: an updated phylogenetic overview of Pleurothallidinae. Lankesteriana, 16(2), 219-241. doi: http://dx.doi. org/10.15517/lank.v16i2.26008

Luer, C. A. (1987). New Lepanthes species from Costa Rica and Panama. Lindleyana, 2, 185-217.

Luer, C.A. (1996). Icones Pleurothallidinarum, XIV: The genus Lepanthes, subgenus Lepanthes in Ecuador. Monographs in Systematic Botany from the Missouri Botanical Garden, 61, 1-255.

Luer, C.A. \& Thoerle, L. (2012). Icones Pleurothallidinarum XXXII. Lepanthes of Colombia (Orchidaceae). Monographs in Systematic Botany from the Missouri Botanical Garden, 123, 1-296.

Pupulin, F. (2001). New taxa in costa rican Lepanthes. Harvard Papers in Botany, 6(1), 289-294. 
Pupulin, F. \& Bogarín, D. (2012). Lepanthes novae Tapantienses. Orchid Digest, 76(1), 20-29.

Pupulin, F. \& Bogarín, D. (2014). Aliae Lepanthes Machogaffenses (Orchidaceae: Pleurothallidinae). Harvad Papers in Botany, 19(2), 194-201. doi: http:// dx.doi.org/10.3100/hpib.v19iss2.2014.n5.

Pupulin, F., Medina, H. \& Bogarín, D. (2011). Two Lepanthes (Orchidaceae: Pleurothallidinae) with strongly reduced corolla. Orchideen Journal, 1(1), 31-35.

Tremblay, R.L., Zimmerman, J.K., Lebrón, L., Bayman, P., Sastre, I., Axelrod, K. \& Alers-García, J. (1998). Host specificity and low reproductive success in the rare endemic Puerto Rican orchid Lepanthes caritensis. Biological Conservation. 85, 297-304. doi: http://dx.doi. org/10.1016/S0006-3207(97)00163-8 